\title{
RECYCLING OF CONSTRUCTION WASTE IN PRODUCTION OF AGGREGATES FOR USE IN THE MANUFACTURE CONCRETE MIXTURES AND FOR ENVIRONMENT PROTECTION
}

\author{
Emhemmad A. Basha ${ }^{1}$, Abd-Raouf J. Al-Tarhouni ${ }^{2}$, Abdullah E. Basha ${ }^{2}$ \\ ${ }^{1}$ Association Professor, Staff member in Department of Civil Engineering, \\ Gasar Ben-Gasher Higher Institute for Comprehensive Professions, Tripoli, Libya. \\ ${ }^{2}$ Master Degree Student in Libyan Academic, \\ Department of Civil Engineering, Janzor, Tripoli, Libya.
}

DOI: 10.46609/IJETSI.2020.v05i01.003 URL: https://doi.org/10.46609/IJETSI.2020.v05i01.003

\section{ABSTRACT}

In general, the solid waste including the remnants of construction and demolition(C\&D) debris significant threat to the environment and public health, where it is believed they are responsible for the spread of many deadly diseases in the communities. So, the disposal is necessary and important to eliminate the most important source of environmental pollution sources, the depending to disposal of this waste on the method of burning, landfill and recycling, but the best way is recycling. The construction waste management means recycling an reuse of these residues as possible in a way to benefit them in other construction work as a source of aggregate cheap price, as well as get rid of these generated quantities for the benefit of the environment protect and its beauty cleaner, as they are considered one of the largest components of sustainable development and a large source of income and the provision of vacant places labor, because of the rapid increase of population and construction in different countries generated billions of tons of construction waste annually so is considered a permanent source of building materials.

Together, these reasons that mentioned above was the goal of this study is to recycle and reuse these construction waste, and use them in the production of the most important structural element in this era and the most widely used in various types of architectural structures where is the concrete material. Work was divided into groups where the first group contained the mixture components of concrete of all waste and the change in the cement ratio of $10 \%$ to $20 \%$ rate of increase $2 \%$, after that find the compressive strength after storage in the water 7 days and compared with the local reference approved \& Nuts, which is consisting of natural cumulus material that magnitude $17.65 \mathrm{~N} / \mathrm{mm}^{2}$ after a storage in the water 7 days. The other groups have 
used natural fine aggregate in the mixture, in addition to test the effect of the amount of water and add substance sikament-163 to the mixture on the compressive strength. Results have shown the best of compressive strength for all the mixtures at all made groups remnants of construction materials was less than the strength of the local reference mixture made from natural materials, but the strength acceptable terms could be used in many construction works that do not require high compression strength resistant, such as the paving of footpaths, squares, parks, storm water channels and others, in addition also noted that the density and specific weight were lower, as for absorption was higher.

Keywords: Ordinary Portland cement, Natural aggregate, construction waste, Sikament-163, Specific weight, Density, Compressive strength.

\section{INTRODUCTION}

Suffer much of the world from the proliferation of landfill construction waste even choked out the streets and roads in the cities, and were scattered over the spaces due to the removal and construction and repair operations. The construction waste is defined as solid waste generated from construction activities and demolition, development and maintenance of the facilities, buildings, roads, bridges, etc., and backward material in locations including asphalt, concrete, brick, wood, glass, plastic, aluminum, iron, insulators, pipes, wires, rubble, stones, marble, ceramic tile and others. This waste should be separated and classified into materials that can be recycled materials; it can be refined and reused as materials and ores after treatment assisting in the construction.

There is no doubt that the protection and conservation of the environment need to develop effective qualitative waste management system in general and construction waste in particular, and that fall including construction waste that can be used again components. Therefore, the optimal employment of construction waste contributes to an active role in reducing the urban project costs and achieve a clean environment and beautiful, no secret what is produced from the various problems of the environment and public health when you leave piles of waste construction on roadsides or in the spaces, so care must be taken to recycle the largest amount possible of these residues for the treatment of the dangers and damage caused by them, which is why conducted and continues to conduct a lot of researches in various countries of the world in how to manage and evaluate construction waste and exploitation and utilization of safe and effective manner [1-6].

\subsection{Effects of Environmental and Health of Construction and Demolition Wastes}

Many of the residues contain chemical substances have negative environmental and health 


\section{International Journal of Engineering Technology and Scientific Innovation}

ISSN: 2456-1851

Volume: 05, Issue: 01 "January-February 2020"

effects in their accumulation in the environment, as well as during disposal operations incineration and land filling. To illustrate more: gas of vinyl chloride is carcinogen substance because they contain active chemical group within the chemical structure, and as it poisonous gas leads to health damage when exposed him even to simple concentration, studies have proved that free vinyl chlorine can cause some types of cancers including liver and brain cancer, also, exposure to dust residues can lead to lung cancer. Use chemicals organic and inorganic as additives contain heavy metals such as lead $(\mathrm{Pb})$, cadmium $(\mathrm{Cd})$, these chemical elements considered toxic elements and when there are the right conditions in the landfill and during the landfill these substances migrate from waste structure to the surrounding medium and then to the soil and water sources, and then to plants and humans.

The presence of compounds Phthalates from within the compounds in the waste and pose a great danger where considers these substances are carcinogenic, causing at long exposure disturbances in endocrine levels hormonal, several countries has prevented use Phthalate Esters in children toys because of the evidence of the transition to the bodies of children and suspected carcinogen in the incidence and impact of an adverse effect on the reproductive system, and considered the United States Agency for safety (US Consumer Products Safety Commission) (USCPSC) that the substance DEHP likely to be carcinogenic to human liver.

The United States Environmental Protection Agency (USEPA) indicated that the Environmental Health Risk (EHR) in America, the primary estimate direct and indirect cost of processing residues and contaminants construction materials diseases are increasing annually are $\$ 30$ billion and $\$ 100$ billion respectively, as a result of the decomposition of the nature of some construction materials and vapors associated with the interaction her with the available air and nature, and here can understand the fear of the acceleration of the high rate and the quality of some of the health ailments, especially respiratory, bronchial asthma, allergic diseases, cancers, kidney failure, liver disease, and others [7].

\subsection{Waste Quintets at the International Level}

Difficult to get accurate information about the amounts, types of construction, demolition and maintenance wastes in the cities to the lack of a data base about these topics, which makes it difficult to give a clear picture of the environmental situation of the management of these wastes. The information available to indicate that the methods used for the management of construction waste and demolition in many countries where are primitive ways does not live up to modern scientific methods in dealing with the waste which depends landfill and incineration of such waste as a major mode, in addition to the small margin of recycling or reuse of these waste, In spite of this, but there are some countries that have been able to achieve the full advantage of the 


\section{International Journal of Engineering Technology and Scientific Innovation}

ISSN: 2456-1851

Volume: 05, Issue: 01 "January-February 2020"

concrete resulting from acts of demolition of buildings, including the Netherlands, Japan, Belgium, Germany, America, Canada, Australia and China.

It is a fact in the world that is extracted 26.6 billion tons per year of almost solid waste, and the share of everyone living on the earth, including 3.8 tons per year. And the total solid waste volume in the European Union are 1300 million tones, $40 \%$ of them or 520 million tons of waste demolition and construction, and more counters extracting is the United States of 325 million tones, followed by Japan produces 77 million tons, then India and China [9].

According to the American National Association of Home Builders (ANAHB) indicated that there are 38 states used the rubble resulting from recycled concrete to the work of the lower layers of the road, and there are 11 states manages the waste concrete and uses in the production of new concrete. As well as the State of Brazil, especially the city of Sao Paulo where was the enactment of the re-use of construction waste and demolition. The State of the Netherlands preventing a longtime establishment dumps or landfills for waste concrete to rebuild the whole recycled, while Finland imposing strict legislation for recycling at demolition sites. As well as Kosovo has established a project to be recycled for the production of aggregates recycled increased by 10 million tons per year. According to the special information of American National Association of Home Builders (ANAHB) in the United States that the disposal wage rate of waste resulting from the construction of 100 houses is estimated 50,000 US \$, while the report of the National Association for the Construction of Housing in America indicates that the cost of disposing of the building or dwelling average size conduct to $\$ 511[10]$.

The estimated of United States Environmental Protection Agency (USEPA1998) that 210 million tons of MSW generated in 1996, and 136 million tons of rubble for construction and demolition generated in the United States during 1996, and the almost of this waste comes from demolition and restored (Building Demolition and Renovation), and the remaining it comes from new construction. And also the United States EPA estimated that the largest proportion of this waste of concrete materials and break the stone where the proportion conducting to $50 \%$ of the total waste buildings. According to statistics of the United States Agency of the amount of construction waste resulting from the demolition of old buildings annually about 200 million tons of construction of houses in towns and villages, resulting in the establishment of new buildings on an area of 2 billion square meters annually remnants of construction of 100 to 120 million tons, and it can have a bad effect on the groundwater of the city water, caused largely disability for healthy development of the city, this act does not protect the environment and will not achieve recycling and efficient use of waste construction. Therefore, experts say it cannot delay the treatment works construction waste, but that will come new market heated to provide the best service to deal with construction waste cities. 
International Journal of Engineering Technology and Scientific Innovation

ISSN: 2456-1851

Volume: 05, Issue: 01 "January-February 2020"

The USEPA (2008) estimated that in 2003, 164 million tons were generated in USA, and in same year estimated that $65-75 \%$ of C\&D debris generated, and was disposal either in C\&D debris land fill. The total amount was 4,248,713 tons/person, which is $2.59 \%$ of total estimated amount generated annual in 2003. The USEPA (1998) indicated that 40-55\% millions tones of C\&D debris is land fill annually, and about $25-40 \%$ were estimated tend to land space, and only about $20-30 \%$ or $25-40$ million tons of C\&D debris are recycled each year. The USEPA (2016) indicated that in 2014,534 million tons of C\&D debris were generated, where concrete was the largest portion $(70 \%)[8]$.

\subsection{Methods of Waste Disposal}

\section{There Is Several Methods Used Today for Waste Disposal, Including:}

\subsubsection{Incineration}

It are more methods widely used today for the disposal of solid waste, despite of the fact that method greatly harm the environment and human, and cause many health problems, including asthma, skin allergies, leukemia, cancers of lung and liver, the incinerated for disposal leads to several many toxic gases such as hydrogen chloride gas emissions ( $\mathrm{HCl}$ ) which cause economic and environmental damage, in addition to health damage where consider this gas is carcinogen substance, also emitted gas of carbon dioxide $(\mathrm{CO} 2)$ and rising per atmospheric air and reduces the concentration of oxygen in the indoor places where cause very danger suffocation, and it is the basic charge on the occurrence of global warming and rising temperatures in the world, as well as also emit carbon monoxide (CO) from combustion processes especially in the presence of a small percentage of oxygen, it is consider a poisonous gas and fought, where this gas combine with the hemoglobin in red blood cells to form carbo oxide hemoglobin, which reduces the blood's ability to transport oxygen to the body's organs and is fatal in case of high concentration, in addition to ash and the rise in temperature to more than $1000 \mathrm{C}^{\mathrm{o}}$ during the burning, and is considered dioxin combines of the most dangerous gases on the environment and public health, where exposure to dioxin causes even small proportions to human infection weak resistance against diseases caused by bacteria, viruses and parasites, which also causes cancer in humans, as pregnant women exposed to dioxin leads to the birth of children suffer from a lack of the male hormone levels and decreased sperm counts in adulthood as well as congenital deformities [1113].

\subsubsection{Landfill}

which means the process of solid waste buried underground, where proved to be ineffective and cause many hazards and environmental pollution significantly, this waste is composed of several 


\section{International Journal of Engineering Technology and Scientific Innovation}

ISSN: 2456-1851

Volume: 05, Issue: 01 "January-February 2020"

different materials including oil chemicals degrade in the heart of the landfill to produce toxic substances that cause contamination of soil and groundwater as one ton waste contaminates almost half a million liters, 500 cubic meters of underground water and drink that human and cause a number of different types of cancers in addition to kidney failure and liver diseases, venereal diseases and other [14].

\subsubsection{Recycle}

It is the process of recycling and use of waste so as to minimize the impact of these wastes and their accumulation on the environment has practical experience in this area confirmed that recycling helps to reduce the cost of raw materials and operating cost, as well as environmental usefulness, previous studies have indicated that some of the material has recycling rates as much as $95 \%$ [15].

So is the re-use and recycling of construction waste and demolition of the best alternative ways for the benefit of the environment. Also, advances in knowledge and the requirements of civil engineering applications such as roads and making cement bricks, as well as in concrete production in large quantities in various construction works. In this day it possible to use waste demolition and construction to increase savings in economic terms, therefore worked several separate research and the scope of wide range and is still taking place in this area to take advantage of demolition waste and construction of the facilities manufacturing concrete from or added to the concrete mixture [16-19], or using recycled aggregate for to product a new concrete, and also in construction [20-24]., were also used in several studies of waste glass in concrete mixtures for various applications in the fields of civil engineering [25], also has both Leah Nango and Aachimil separate the two papers using construction waste in the production of cement bricks [26, 27]. In the Eanordo study and colleagues have used the recycled waste sand in the production of bricks used in paving roads and streets. [28] Uy Shak and Others studied effect of partial replacement of fine aggregate by powder on fresh and hardened Properties of SCC [29].

\subsubsection{Recycle Advantages of Wastes}

1. Sanitary maintain of sites landfills as significant in the areas as well as the preservation of the environment.

2. Considered a type of economic income for the country.

3. Reduce the cost paid for landfills, other transport fares and wages.

4. Reduce the proportion of resource depletion and negative effects on the environment.

5. Provide savings in energy costs.

6. Recycling process on site is common in the implementation of large construction projects 
as a way to avoid the cost of transport.

7. Material revenues generated from the sale of selected materials recycled.

8. Establishment of new factories and the provision of vacant places of employment.

9. Obtain of economic concrete.

10. Exploit local resources recycling to dispense of the imported materials.

11. Used in the production of cement bricks for construction the walls of buildings.

12. Used in the paving of the streets of residential neighborhoods.

13. Used in the construction of gardens and parks.

\subsubsection{The Aim of the Study}

1. Get rid of these waste recyclers to take advantage of them as much as possible.

2. Reduce the material cost of aggregates used in concrete production.

3. Provide the lands previously occupied landfill sites and landfill waste from these areas.

4. Protect the environment from pollution which is caused by the accumulation.

5. The depth of study it scientifically and working of testing for to understand their behavior for to try to utilize advantage of broader areas.

2. MATERIALS, EXPERIMENTS, EQUIPMENT'S USED AND THE PRACTICAL PROGRAM

\subsection{Materials Used}

\subsubsection{Wastes of Construction Demolition}

It was obtained the construction waste from the output of demolition of some buildings, maintenance and construction of Qasar bin-Ghashir city, which lies southeast of Tripoli a distance of 25 kilometers. It have been separating undesirable materials such as wood, plastic, iron, glass, etc., it has also been manually crushed and then practice by standard sieves to be matching the American specification maximum of $(20 \mathrm{~mm})$.

\subsubsection{Cement}

Cement used in this research is an Ordinary Portland Cement where obtained from Sooq Alkhames factory which is located southeast of city of Tripoli, a distance of $70 \mathrm{~km}$, which is classified on the strength of 42.5 Newton, according to British specifications (BS).

\subsubsection{Sand}

Sand user was supplied from the local market and extracted from quarries Zleten and classified 
according to Libyan specification No. (49) of fine aggregate (sand).

\subsubsection{Water}

Water used in this research were obtained from the water city of Qasr bin Ghashir network which is safe to drink and use in construction projects according to the Libyan specifications of waters.

\subsubsection{Sikament-163}

Have been getting this material from the local market and is used as a highly efficient to reduce the water content, and strong as a plasticizer increases high degree of workability for the production of concrete type of high quality in a warm climate. And leads the dual effect of improving the speed of hardening and increase early and final stresses, and it is a matching British and American specifications (ASTM C 49 type F and B.S.5075 part 3 for super plasticizer).

\section{TESTS AND EQUIPMENT'S USED}

\subsection{Specific Weight of Aggregate}

This test was conducted to aggregate user of waste, according to US descriptors (ASTM-8541958).

\subsection{Absorption Ratio of Coarse Aggregate and Fine Aggregate}

The determination of absorption ratio of aggregates is of great importance because it is when used in its dry, it will absorb part of the mixing water for the purpose of access to the saturated condition, which leads to reduction of the effective mixing water. The share is calculated absorption of a sample of coarse aggregate or fine aggregate (sand) used in this research, so its weight which is internal saturated and dry surface after immersion for 24 hours (W1), then dried in the oven at a temperature of $110^{\circ} \mathrm{C}$ for 24 hours and weighed after removing from the oven and cooled for two hours (W2), and the ratio of absorption of the sample under the following equation:

Absorption ratio $(\%)=(\mathrm{W} 2-\mathrm{W} 1 / \mathrm{W} 2) 100$

\subsection{Equipment of Compressive Strength Measurement}

Compressive Strength Machine Serial Number: (1796-8-2539) (International E L E)

It have been measuring the compressive strength of different samples ages (7, 14, 28 days) 
according to the American specification number (ASTM C39) by means of compressive strength machine described above, it is through the load to the point of collapse, after that calculate the compressive strength of the quotient of load causes to collapse on the face of the cube exhibition of concentrated load of the compressive strength machine, as shown in the following equation:

Stress: $\sigma=\mathrm{P} / \mathrm{A}$

Where: $\sigma=$ pressure or stress resistance. $\mathrm{P}=$ load. $\mathrm{A}=$ area of cube face.

\section{PRACTICAL PROGRAM}

Practical program addresses four proposals for testing of concrete mixture: 1 . when a change in the ratio of cement, 2. adds the natural fine aggregate, 3. change in the percentage of water. 4.

And add different percentages of sikament substance-163. From table (1) to table (4) show all the program of laboratory work.

Table 1: Illustrated the tests at variation of cement proportions

\begin{tabular}{|c|c|c|c|c|c|c|c|c|}
\hline \multicolumn{4}{|c|}{ Mix natural reference } & \multirow[b]{2}{*}{$\begin{array}{l}\text { Test } \\
\text { No. }\end{array}$} & \multicolumn{4}{|c|}{ Laboratory mixture } \\
\hline Cement & Water & $\begin{array}{c}\text { Fine } \\
\text { aggregate }\end{array}$ & $\begin{array}{c}\text { Coarse } \\
\text { aggregate }\end{array}$ & & Cement & Water & $\begin{array}{c}\text { Waste of fine } \\
\text { aggregate }\end{array}$ & $\begin{array}{c}\text { Waste of coarse } \\
\text { aggregate }\end{array}$ \\
\hline \multirow{6}{*}{$11.07 \%$} & \multirow{6}{*}{$9.15 \%$} & \multirow{6}{*}{$28.98 \%$} & \multirow{6}{*}{$50.80 \%$} & 1.1 & $10 \%$ & $9.15 \%$ & $29.29 \%$ & $51.56 \%$ \\
\hline & & & & 1.2 & $12 \%$ & $9.15 \%$ & $28.71 \%$ & $51.46 \%$ \\
\hline & & & & 1.3 & $14 \%$ & $9.15 \%$ & $28.13 \%$ & $48.74 \%$ \\
\hline & & & & 1.4 & $16 \%$ & $9.15 \%$ & $27.55 \%$ & $47.30 \%$ \\
\hline & & & & 1.5 & $18 \%$ & $9.15 \%$ & $26.97 \%$ & $45.88 \%$ \\
\hline & & & & 1.6 & $20 \%$ & $9.15 \%$ & $26.39 \%$ & $44.46 \%$ \\
\hline
\end{tabular}

Table 2: Show the tests at variation of the fine sand waste ratio by alternative of natural sand

\begin{tabular}{|c|c|c|c|c|c|c|c|c|c|}
\hline \multicolumn{4}{|c|}{ Mix natural reference } & \multirow{2}{*}{$\begin{array}{l}\text { Tet } \\
\text { No. }\end{array}$} & \multicolumn{5}{|c|}{ Mix laboratory reference } \\
\hline \multirow[t]{3}{*}{ Cement } & Water & $\begin{array}{c}\text { Fine } \\
\text { aggregate }\end{array}$ & $\begin{array}{c}\text { Coarse } \\
\text { aggregate }\end{array}$ & & Cement & Water & $\begin{array}{c}\text { Fine } \\
\text { aggregate } \\
\text { waste }\end{array}$ & $\begin{array}{c}\text { Fine } \\
\text { aggregate } \\
\text { natural }\end{array}$ & $\begin{array}{c}\text { Coarse } \\
\text { aggregate } \\
\text { waste }\end{array}$ \\
\hline & & & & 2.1 & $14 \%$ & $9.15 \%$ & $21.10 \%$ & $7.03 \%$ & $48.74 \%$ \\
\hline & & & & 2.2 & $14 \%$ & $9.15 \%$ & $14.07 \%$ & $14.07 \%$ & $48.74 \%$ \\
\hline
\end{tabular}


International Journal of Engineering Technology and Scientific Innovation

ISSN: 2456-1851

Volume: 05, Issue: 01 "January-February 2020"

\begin{tabular}{|c|c|c|c|c|c|c|c|c|c|}
\hline & & & & 2.3 & $14 \%$ & $9.15 \%$ & $7.03 \%$ & $21.10 \%$ & $48.74 \%$ \\
\hline $11.07 \%$ & $9.15 \%$ & $28.98 \%$ & $50.80 \%$ & 2.4 & $14 \%$ & $9.15 \%$ & $00 \%$ & $28.13 \%$ & $48.74 \%$ \\
\hline
\end{tabular}

Table 3: Illustrate the tests at variation of the water proportion of mix

\begin{tabular}{|c|c|c|c|c|c|c|c|c|}
\hline \multicolumn{4}{|c|}{ Mix natural reference } & \multirow{2}{*}{$\begin{array}{l}\text { Test } \\
\text { No. }\end{array}$} & \multicolumn{4}{|c|}{ Mix laboratory reference } \\
\hline Cement & Water & $\begin{array}{c}\text { Fine } \\
\text { aggregate }\end{array}$ & $\begin{array}{c}\text { Coarse } \\
\text { aggregate }\end{array}$ & & Cement & Water & $\begin{array}{c}\text { Fine } \\
\text { aggregate } \\
\text { waste }\end{array}$ & $\begin{array}{c}\text { Coarse } \\
\text { aggregate } \\
\text { waste }\end{array}$ \\
\hline \multirow{4}{*}{$11.07 \%$} & \multirow{4}{*}{$9.15 \%$} & \multirow{4}{*}{$28.98 \%$} & \multirow{4}{*}{$50.80 \%$} & 3.1 & $14 \%$ & $9.15 \%+2 \%$ & $28.13 \%$ & $48.74 \%$ \\
\hline & & & & 3.2 & $14 \%$ & $9.15 \%+5 \%$ & $28.13 \%$ & $48.74 \%$ \\
\hline & & & & 3.3 & $14 \%$ & $9.15 \%-2 \%$ & $28.13 \%$ & $48.74 \%$ \\
\hline & & & & 3.4 & $14 \%$ & $9.15 \%-5 \%$ & $28.13 \%$ & $48.74 \%$ \\
\hline
\end{tabular}

Table 4: Shows the testes at added the sikament-163

\begin{tabular}{|c|c|c|c|c|c|c|c|c|c|}
\hline \multicolumn{4}{|c|}{ Mix natural reference } & \multirow{2}{*}{$\begin{array}{l}\text { Test } \\
\text { No. }\end{array}$} & \multicolumn{5}{|c|}{ Mix laboratory reference } \\
\hline $\begin{array}{c}\text { Cement } \\
(\%)\end{array}$ & $\begin{array}{c}\text { Water } \\
(\%)\end{array}$ & $\begin{array}{c}\text { Fine } \\
\text { aggregate } \\
(\%)\end{array}$ & $\begin{array}{c}\text { Coarse } \\
\text { aggregate } \\
(\%)\end{array}$ & & $\begin{array}{c}\text { Cement } \\
(\%)\end{array}$ & $\begin{array}{c}\text { Sikament/cement } \\
(\%)\end{array}$ & $\begin{array}{r}\text { Water } \\
(\%)\end{array}$ & $\begin{array}{c}\text { Fine } \\
\text { aggregate } \\
\text { waste } \\
(\%)\end{array}$ & $\begin{array}{c}\text { Coarse } \\
\text { aggregate } \\
\text { waste } \\
(\%)\end{array}$ \\
\hline \multirow{3}{*}{11.07} & \multirow{3}{*}{9.15} & \multirow{3}{*}{28.98} & \multirow{3}{*}{50.80} & 4.1 & 14 & 0.6 & 9.15 & 28.13 & 48.74 \\
\hline & & & & 4.2 & 14 & 1.5 & 9.15 & 28.13 & 48.74 \\
\hline & & & & 4.3 & 14 & 2.5 & 9.15 & 28.13 & 48.74 \\
\hline
\end{tabular}

\section{PROCESSING AND SAMPLE PREPARATION}

\subsection{Sample Processing}

During the samples processing should be following these steps:

First: calculate the weight ratios of the rubble of construction waste to mix reference laboratory based on the ratio of the weight of the sand and natural aggregates, cement used in the concrete mix regular local reference in accordance with the specifications of the Libyan as shown in the table (5). 
Volume: 05, Issue: 01 "January-February 2020"

Second: All mixtures were calculated in each group based on a practical program subject in advance and is described in the tables of the action plan mentioned above.

Third: preparing standard rail moldings which are according to the specification, where should be clean and paint the interior surfaces with oil.

Table 5: Illustrated the combines and weights of normal concrete mix per meter cubic according to the Libyan specification

\begin{tabular}{|c|c|c|}
\hline Concrete mix combines & $\begin{array}{c}\text { Weight } \\
(\mathbf{k g})\end{array}$ & $\begin{array}{c}\text { Percent of mix combines } \\
(\boldsymbol{\%})\end{array}$ \\
\hline Cement & 260 & 11.07 \\
\hline Fine aggregate & 680 & 28.96 \\
\hline Water & 215 & 9.16 \\
\hline Coarse aggregate & 1193 & 50.81 \\
\hline
\end{tabular}

\subsection{Preparation of Samples}

Mix the content of each sample without the addition of water for a few minutes to make sure the spread and mixing the rubble of waste very well with cement, and then add the water gradually and continue mixing until the mix well with the water, and in harmony inside the rubble, then pour the mixture into the mold on three layers each layer tamping 25 times by a special rod prepared for this task in accordance with the specifications, then it evens the surface very well and leave for 24 hours, after that has been lifting the template and sample immersed in water treatment to the period stipulated in the action plan. After the end of the required treatment of samples are conducting the required tests according to the required plan.

\section{RESULTS AND DISCUSSION}

\subsection{Results of specific weight, density and absorption}

Through the results obtained from laboratory tests private coarse and fine aggregates wastes conclude that the specific weight of course is 2.131 which is less than the natural aggregates where usually have an average of 2.65 , while the dry density of concrete made from the aggregate of waste was $2205 \mathrm{~kg} / \mathrm{m}^{3}$ and this result is less than concrete dry density which made from of natural aggregates, which must be between $2200 \mathrm{~kg} / \mathrm{m}^{3}$ to $2600 \mathrm{~kg} / \mathrm{m}^{3}$.

The absorption of coarse aggregates of waste is $11.12 \%$, which is much higher than natural 
Volume: 05, Issue: 01 "January-February 2020"

aggregates, which ranges between $0.5 \%$ to $1 \%$, and the reason attributed to the proportion voids of aggregate waste higher than natural aggregate, resulting in lower specific weight of the dry density and an increase in the absorption ratio which is the highest of specifications where equal to $10 \%$.

\subsection{Compressive Strength}

\subsubsection{Group 1: When the Change the Ratio of Cement Added to the Mixture at Storage Period Time of 7 Days, 14 Days, and 28 Days.}

Table (6) shows the results of compressive strength resistance at the increase and decreases the cement ratio for the reference mixture (according to the specifications of the Libyan cement concrete at $14 \%$ ) at various period time storage, and figure (1) represents these results. Through the results note the strength of the pressure resistance reduced at all storage of period time when add $10 \%$ and $12 \%$ where lower than the reference cement ratio $(14 \%)$. Whereas, when cement ratio adds to $16 \%, 18 \%$, and $20 \%$ which is higher than the reference proportion, find the strength has increased at all of these proportions, but it is still less than the compressive strength of the local mix resistance (reference strength). Through these results also note the best value for the compressive strength resistance was obtained by adding $14 \%$ cement to the mixture, for this reason was chosen as a reference laboratory.

Table 6: Show results of compressive strength for group 2 at used natural sand with $14 \%$ of cement.

\begin{tabular}{|c|c|c|c|c|c|}
\hline \multirow[t]{2}{*}{ Group } & \multirow[t]{2}{*}{ Test No } & \multirow[t]{2}{*}{ Cement Average } & \multicolumn{3}{|c|}{ Average of compressive strength $\left(\mathrm{N} / \mathrm{mm}^{2}\right)$} \\
\hline & & & 7 days & 14days & 28days \\
\hline \multirow{8}{*}{1} & 1 & $10 \%$ & 5.3 & 6.4 & 7.4 \\
\hline & 2 & $12 \%$ & 6.3 & 7.7 & 10.5 \\
\hline & 3 & Lab. reference $14 \%$ & 11.9 & 14.1 & 12.4 \\
\hline & 4 & $16 \%$ & 12.2 & 11.6 & 11.8 \\
\hline & 5 & $18 \%$ & 11.9 & 13.3 & 10.6 \\
\hline & 6 & $20 \%$ & 13.5 & 13.5 & 13.5 \\
\hline & 7 & $10 \%$ & 5.3 & 6.4 & 7.4 \\
\hline & \multicolumn{2}{|c|}{ Local production $14 \%$} & \multicolumn{3}{|c|}{ Local strength $17.65\left(\mathrm{~N} / \mathrm{mm}^{2}\right)$} \\
\hline
\end{tabular}




\section{International Journal of Engineering Technology and Scientific Innovation}

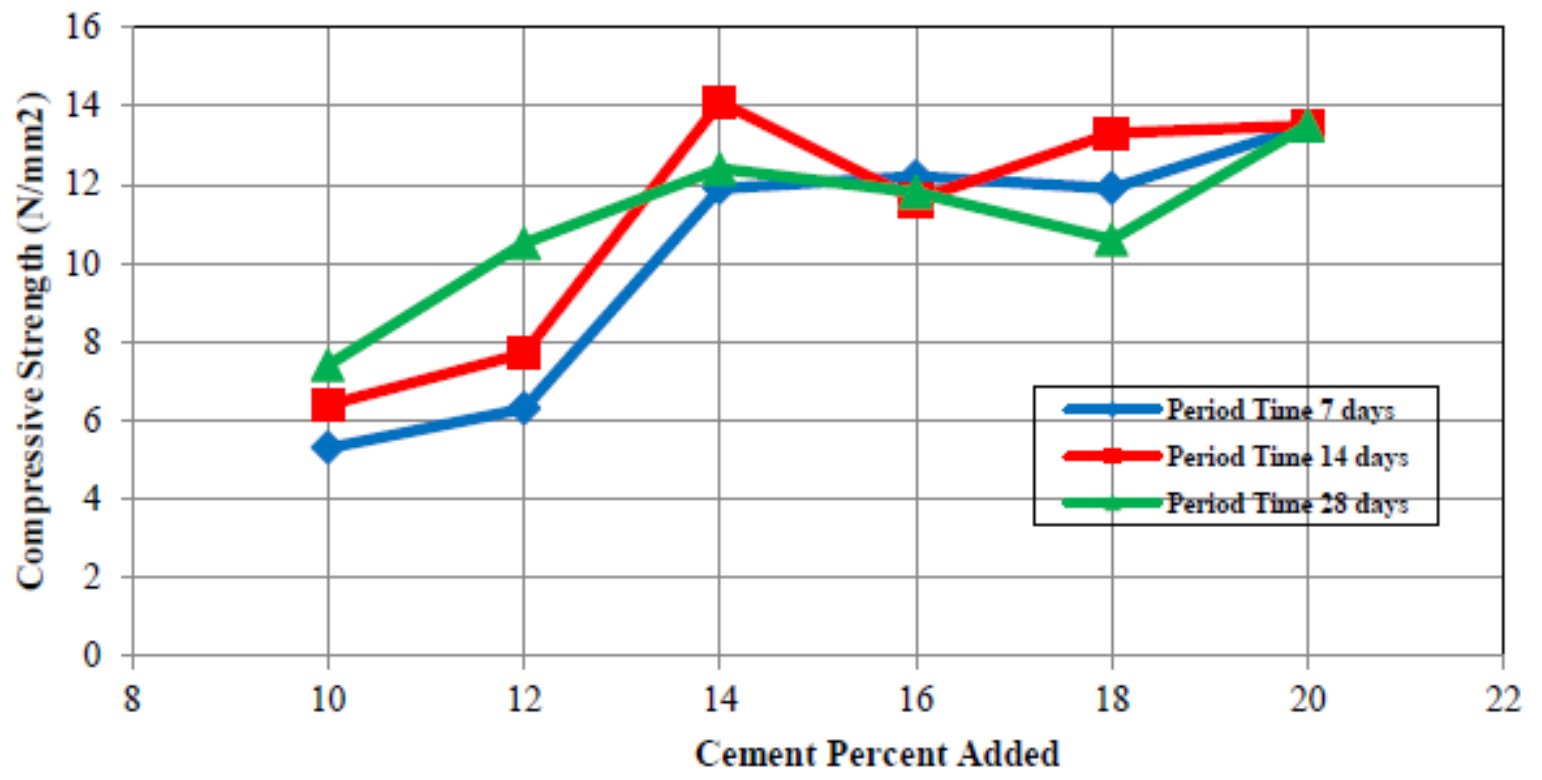

Fig. 1: Relationship between cement add and compressive strength

In the fact, the reduction the compressive strength of resistance at all ratios added compared with the local mixture which made from natural materials may cause attributed to several possibilities: firstly; the local mixture composed from natural aggregates is strongest than the aggregate of the waste, where it is the largest densities and greater qualitative weight. Secondly: the percentage of voids in the aggregate of wastes is much more than in the natural aggregates. Third: insufficient proportion of amount of water due to high absorption of the waste aggregate, this attributed to the high percentage of the pores in the waste aggregate, spite of taking precautions by adding the proportion of higher absorption of waste aggregate prescribed percentage. Fourth: is probably insufficient quantity of cement additives, which are commensurate with the quality of this aggregate waste.

Through figure (2), which represents the relationship between the compressive strength and the period time of storage, note the storage period time did not have any effective impact in increasing the strength of the pressure resistance in only one case at add the $12 \%$ cement, where terms of power evolved from $6.30 \mathrm{~N} / \mathrm{mm}^{2}$ to $10.50 \mathrm{~N} / \mathrm{mm}^{2}$, in the period time between 7 days to 28 days. 


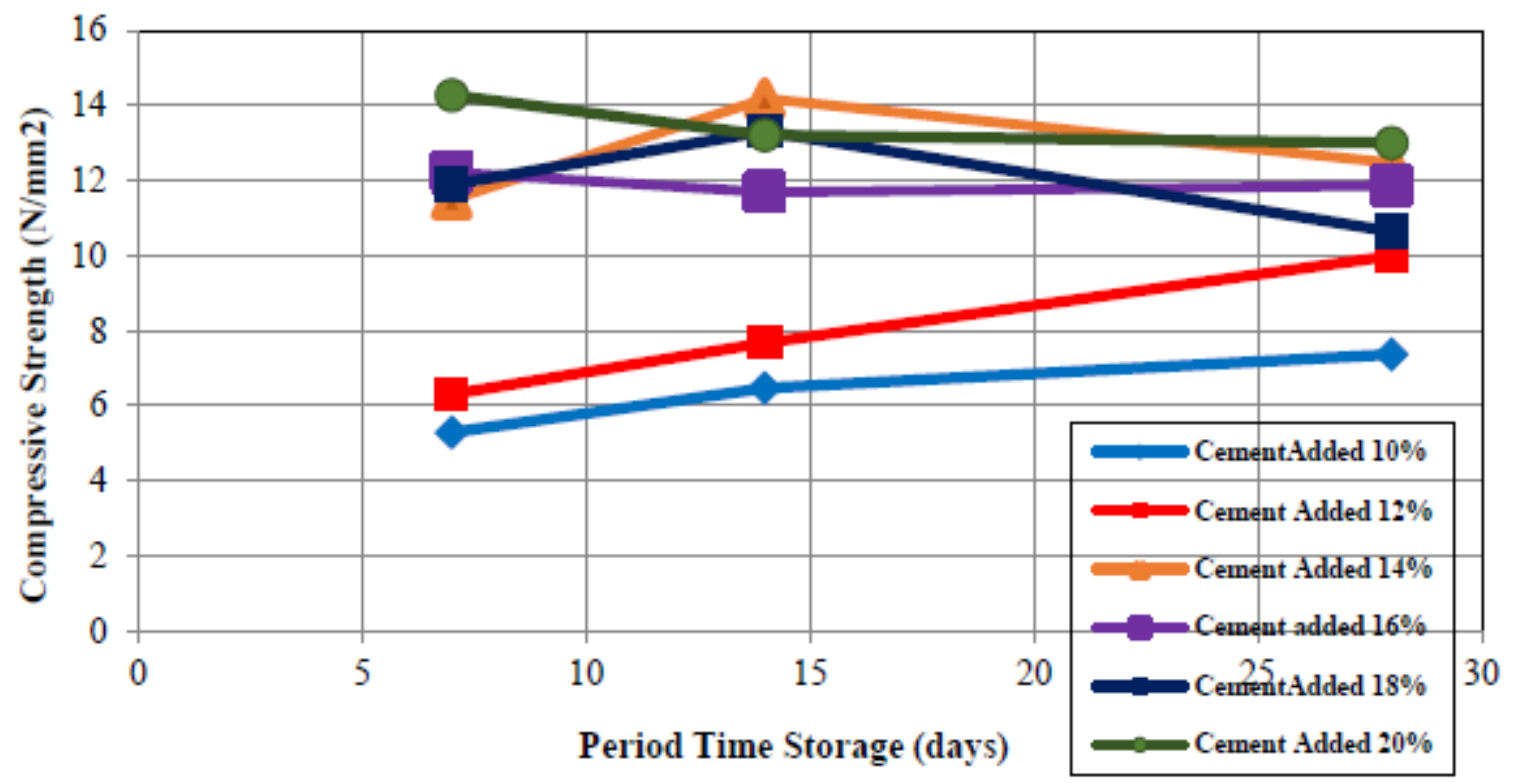

Fig. 2: Relationship between compressive strength and period time storage

It could be argued the use of construction and demolition wastes in concrete production, which is considered one of the means to disposal of this waste in order to protect the environment with its investment, exploitation and utilization in several engineering applications, and it is not only that but also includes the following:

1. Product features lightweight because aggregate waste density less than the density of natural aggregate.

2. Economically, the costs of concrete which made from construction and demolition waste is less expensive than concrete made from natural materials.

3. The use of these wastes to achieve a clean and beautiful environment.

\subsubsection{Group 2: The Change Ratio of Fine Aggregate Waste with Natural Fine Aggregate at the Rate of $14 \%$ Cement and 7 Days Period Time of Storage.}

In this group, which has been used natural fine aggregate at different ratios instead of waste of fine aggregate, noted through the results where illustrated in the table (7), and which is represented by figure (3) as a relationship between the proportion of fine aggregate added and compressive strength, the addition of natural aggregates as an alternative to fine aggregate waste did not have any significant influence in the development of resistance to compressive strength, as the value of all the results have been less than the value of the local compressive strength and compressive strength of reference laboratory. Through the figure note the conduct of the curve 
Volume: 05, Issue: 01 "January-February 2020"

decreases as the increase the proportion of added natural fine aggregate to the mix, and also note from the curve the best value obtained was at add the proportion (75\%) of natural aggregate, but it is still less than the local compressive strength and reference laboratory. In the fact the reason for lack of development of strength, it may be due to reason, for an increase in the voids which is caused by addition of natural aggregates for changed distributional volumetric granules, which in turn shook the suitability of both the amount of water and quantity of cement in the mixture.

Table 7: Show results of compressive strength of group 2 at used natural sand with $14 \%$ cement

\begin{tabular}{|c|c|c|c|c|c|}
\hline Group & Test & $\begin{array}{c}\text { Cement ratio } \\
(\%)\end{array}$ & $\begin{array}{c}\text { Ratio of natural } \\
\text { sand } \\
(\%)\end{array}$ & $\begin{array}{c}\text { Pass ratio of wastes } \\
\text { through sieve open } 2.36 \\
\text { mm } \\
(\%)\end{array}$ & $\begin{array}{l}\text { Average of compressive } \\
\text { strength }\left(\mathrm{N} / \mathrm{mm}^{2}\right) \\
7 \text { days period time }\end{array}$ \\
\hline & 1 & 14 & 25 & 75 & 9.32 \\
\hline & 2 & 14 & 50 & 50 & 9.00 \\
\hline & 3 & 14 & $\% 75$ & 25 & 10.45 \\
\hline 2 & 4 & 14 & $\% 100$ & 0 & 8.72 \\
\hline & \multicolumn{4}{|c|}{ Laboratory reference ( $14 \%$ cement) } & \\
\hline & \multicolumn{4}{|c|}{ Local production ( $14 \%$ cement) } & \\
\hline
\end{tabular}

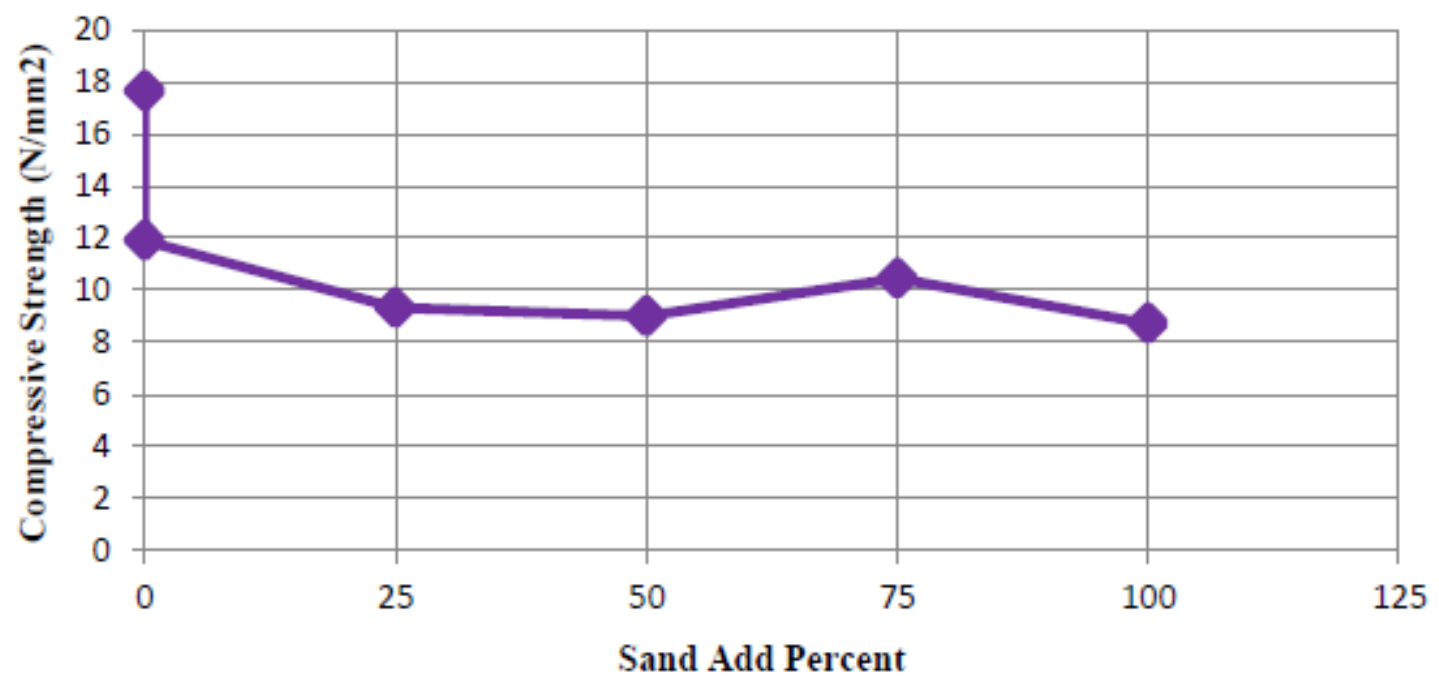

Fig. 3: Relationship between sand add percent and compressive strength 


\subsubsection{Group 3: When Change the Water Proportion of Higher and Lower Than in the Reference Mixture for a Period of 7 Days Storage.}

Through the results contained in the table (8), which is represented by figure (4), a relationship between the compressive strength and the percentage change in the amount of water, where increases and decreases $0.5 \%$ and $0.2 \%$ of ratio used in local reference mixtures and laboratory reference. Through results note all the values of compressive strength were less than strength of both the mix of laboratory and domestic in both cases at increase or decrease the percentage of water than the rate used in reference mixture $(9.15 \%)$, and this indicates the water may play an important role in the increase or decrease the strength, also note the $9.15 \%$ is the best ratio in this case, also note the lack of development of strength due to the weak strength to the consisting compound from waste materials, where is weaker than natural materials, in addition to the high proportion of pores in the aggregate waste.

Table 8. Illustrated results of compressive strength at variation in added water ratio of increase and decrease to lab. Reference mix at 7 days period time.

\begin{tabular}{|c|c|c|c|}
\hline \multirow{4}{*}{ Group } & Test No. & Water ratio & $\begin{array}{c}\text { Average of compressive strength } \\
\text { (N/mm2) for 7days period time }\end{array}$ \\
\hline \multirow{7}{*}{} & Local & $9.15 \%$ Reference & 17.65 \\
\cline { 2 - 5 } & Lab. & $9.15 \%$ Reference & 11.9 \\
\cline { 2 - 5 } & 1 & $-0.05 \%$ Under Reference & 11.1 \\
\cline { 2 - 5 } & 2 & $-0.02 \%$ Under reference & 9.7 \\
\cline { 2 - 5 } 3 & 3 & $+0.05 \%$ Above reference & 8.0 \\
\cline { 2 - 4 } & 4 & $+0.02 \%$ Above reference & 5.9 \\
\hline
\end{tabular}




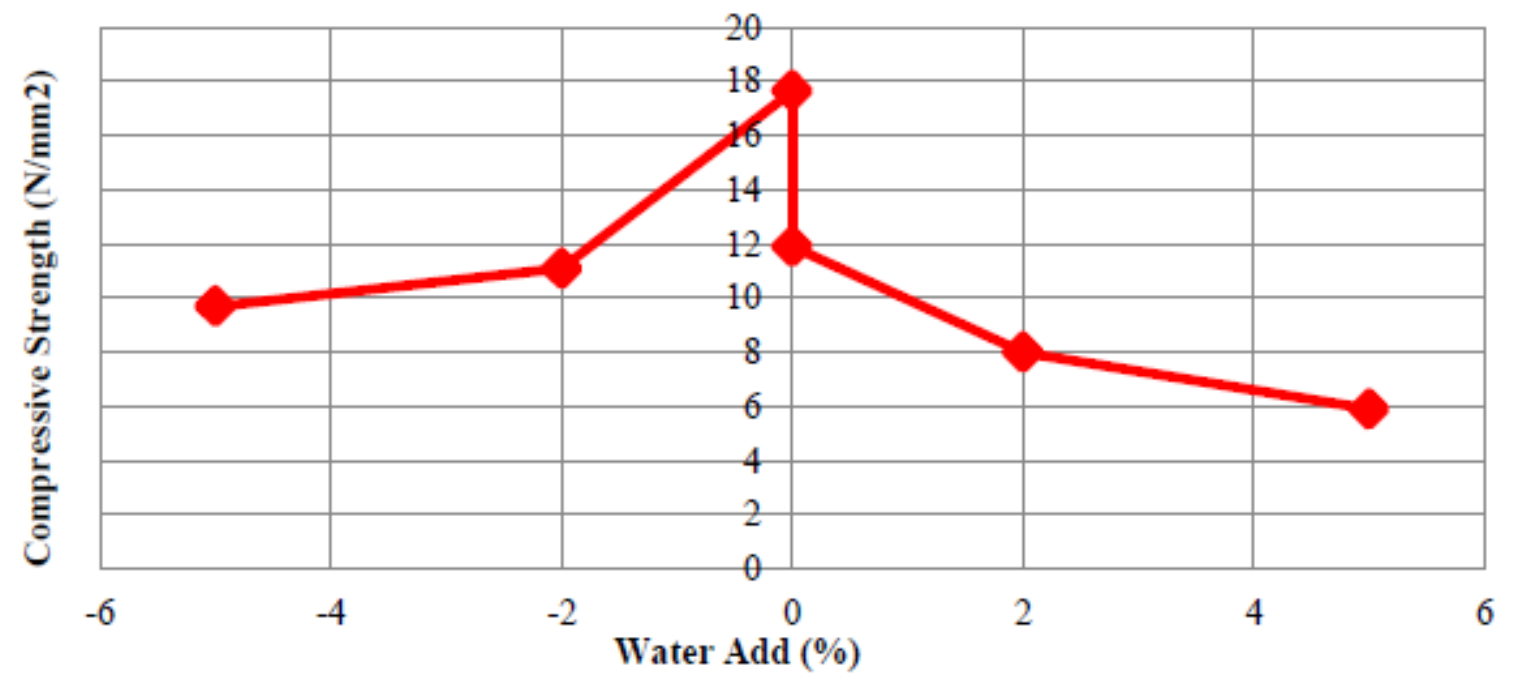

Fig. 4: Effect of add water on the compressive strength up and down of references water of mixture

\subsubsection{Group 4: When Add Sikament -163 to the Mixture Reference Laboratory.}

Through the results contained in the table (9) and through figure (5) note the addition of sikament by different proportions to the concrete mix had no effect on increasing compressive strength of concrete compared to local reference and laboratory reference of mixtures, but the results were reversed expected to have decrease for a strong reference mixtures.

Table 9: Illustrates the results of compressive at sikament- 163 added with proportions variation in the reference mix at 7 days period time.

\begin{tabular}{|c|c|c|c|c|}
\hline Group & $\begin{array}{c}\text { Test } \\
\text { No }\end{array}$ & $\begin{array}{c}\text { Sikament ratio/cement } \\
\text { ratio }\end{array}$ & $\begin{array}{c}\text { Wate } \\
\mathbf{r} \\
\text { ratio }\end{array}$ & $\begin{array}{c}\left.\text { Average stresses (N/ } \mathbf{m}^{2}\right) \text { for 7 days } \\
\text { period time }\end{array}$ \\
\hline \multirow{4}{*}{4} & Local & 0 & 9.15 & 17.6 \\
& Lab. & 0 & 9.15 & 11.9 \\
\cline { 2 - 5 } & 1 & 0.6 & 4.5 & 6.17 \\
\cline { 2 - 5 } & 2 & 1.50 & 4.5 & 8.77 \\
\cline { 2 - 5 } & 3 & 2.50 & 4.5 & 7.57 \\
\hline
\end{tabular}




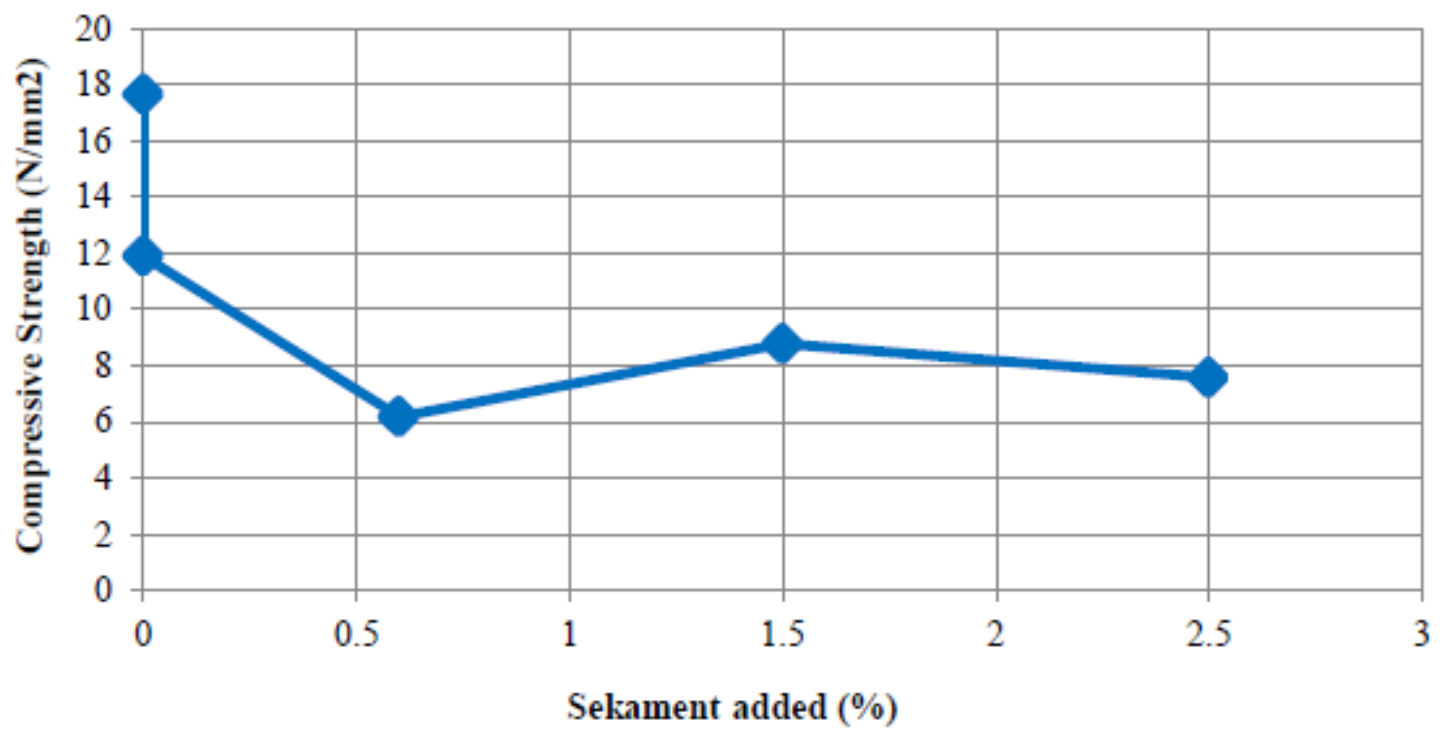

Fig. 5: Effect of added sekament to the mixtur on the compressive strength

\section{CONCLUSIONS}

1. The results showed, both the specific weight and density of the aggregate of construction waste were less than domestic natural aggregates user.

2. The results showed the absorption value of aggregate waste was higher than domestic natural aggregates.

3. During the laboratory, the study did not show any results that were obtained when using waste the compression strength is higher or equal the compressive strength of concrete used in domestic natural aggregates.

4. The results showed the compressive strength of concrete used construction wastes did not increase with increase period time storage for all samples.

5. The results illustrated, the compressive strength of concrete using the waste of construction increase with increases the proportion of cement, despite the fact that a slight increase.

6. The results clarified the influenced compressive strength values depending on the variation of add water ratio.

7. The results showed the compressive strength of concrete has decreased with increased natural fine aggregate to the mixture.

8. The results showed the compressive strength at add sikament substance ratios $(0.6 \%$, $1.55 \%, 2.5 \%$ ) had reduced the strength.

9. Through these results obtained from this research the concrete made from the waste of construction materials can be used in many applications of civil engineering such as 
International Journal of Engineering Technology and Scientific Innovation

ISSN: 2456-1851

Volume: 05, Issue: 01 "January-February 2020"

parking floors, concrete paving of roads, footpaths, cubes of concrete, cement bricks channels of waste water, returning wall, lining the sides of roads, fences of gardens and farms and etc.

\section{REFERENCES}

[1]. Zezhou. W., Honggin. F., and Guiwen. L., "Forecasting Construction and Demolition Waste Using Gene Expression Programming". Journal of Computing in Civil Eng. 2013.

[2]. Jian. C, Shwang. L. and Weiwei. H., "Urban Construction Wastes Resource Utilization Inquiry". ICCREM 2014: 382 - 3888. 2014.

[3]. Tamraz. S. N., et.al., "Construction Demolition Waste Management in Lebanon”. ICSDC 2011. $375-383$.

[4]. Jing. Z., et.al., "Waste based Management in Residential Construction" Journal of Construction Engineering and Management, Vo. 131, Vo.4, pp. 423 - 430. Apr. 2013.

[5]. Wei. Z, and Qingmeiwu., "Development Model for Construction Waste Management of China". ICSDC 2011: 421 - 430.

[6]. Samanoh. Z, et. al., "Environnemental Impact Sassement on Construction Sites" Construction Research Congres 2012 : 1750 - 1759.

[7]. Ahmed Hamza., "Caveats and Environmental Health for The Use and Recycling of Plastic Waste", Arab Seminar to Rotate the Plastic Waste, Cairo - Egypt, pp (1-4, 12-14). 2007.

[8]. Andria Vachon., Economic and Environmental consideration and for construction and demolition (C\&D) debris management and policy (2008). Masters theses and capstones, 403. Thesis master degree, university of New Hampshire, Durham, fall (2008).

[9]. N. Scarlat and et al., "Evaluation of Energy Potential of Municipal Solid Waste from Africa Urban Areas. Academic Journal of Renewable and Sustainable Energy Review, 50 (2015) 1260-1286

[10]. Holly L. Story; "The recycling and Reuse of C\&D Débris" Université of South Californie, American National Association of Home Boulders (ANAHB). Institute for public Service and Policy research. Vol 3 No 3, www.Iopa.Sc.edu

[11]. Abdul Hamid Dign, and Others ., "Attended The Reasons Many Material Vinyl Chloride (PVC)", Scientific Meeting on Science and Environmental Technology, (2004), Tripoli Libya.

[12]. Pat Costner, "Dioxin elimination", published by Greenpeace International Amsterdam, the Netherlands. 2000.

[13]. Bhandere P.S, Lee B.K, and Krishnan K., "Study of pyrolysis and International of Disposable Plastics Using Combined", TG/FT_IR Technique, Journal of Thermal Analysis, (1997). 
International Journal of Engineering Technology and Scientific Innovation

ISSN: 2456-1851

Volume: 05, Issue: 01 "January-February 2020"

[14]. Muthanna Abdul Razzaq Age, "Environmental Pollution", Dar Weal For Publication, First Edition, Amman, Jordan. (2000),

[15]. European Environmental Agency, "Environment in European Union at the Turn of the Century", .Environmental Assessment Report No. 2. ISBN 92-9157-202-0. Copenhagen. 1999.

[16]. Giogio F., Mistuya M., Alberto F. (2014); "New Sustainable Technology for Recycling Returned Concrete"., Construction and Building Materials. Vol. 67, part C, 30 Sep. 2014, pp $363-659$.

[17]. Gomes M, De Birto J, and Bravo M., "Mechanical Performance of Structural Concrete With the Incorporation of Coarse Recycled Concrete and Ceramic Aggregate". $J$. Materials Civil Eng. 26(10), 04014076(2014).

[18]. Adrinola O. S., and et. al., "Investigating the Suitability of Previous Concrete in Improving Environmental Qualities.EJGE. Vol. 19 [2014], Bund. H.

[19]. Chaojie Yi, et. al., "The Recovery and Utilization of Construction Waste: Waste Concrete". ICCREM 2013: 271 - 279. (2013).

[20]. Sami W, Akmal S. A., "Influence of Recycled Concrete Aggregate on Strength Properties of Concrete". Construction and Building Materials. Vol. 23, ISSUE 2, Feb. 2009, pp 1163 - 1167. (2009).

[21]. Monalisa B. et. al. "Recycled Aggregate From C \& D Waste and It Is Use in Concrete a Bricks Rough Towards Sustainability in Construction Sector. Construction and Building Materials.15 Oct. 2014, Vol. 68, pp $501-516$.

[22]. Nwzad Abduljabar Abdulla, "Effect of Recycled Coarse Aggregate Type on Concrete". Journal of Materials in Civil Engineering. Publication Date: 30 December 2014.

[23]. Inthikab H, and et al. (2014); "Evaluation of the Mechanical Performance of Recycled Concrete Aggregate Used in Highway Base Layers". Geo-Congress 2014, Technical papers: $3686-3694$.

[24]. Shubham Bhardwaj and et. al.; " Use Recycled Concrete Aggregate in Construction" IJETER. Volume 4, Issue 10, October (2016).

[25]. Nasser Almesfer and Jason Lngham, "Effect of Waste Glass on the Properties of Concrete" J. Materials Civil Eng. 26 (11) 06014022 (2014).

[26]. Lianyang Zhang, "Production Bricks From Waste of Materials". Construction and Building Materials. Vol. 47, Oct. 2013, pp. 643 - 656. (2013).

[27]. Eshmail. G, Ghassan J, and Homayoon S, "Reducing Cement Contents of Paving Blocks by Using Minerals Waste and by-Product Materials". J. Materials Civil Eng. 27(1), 0401406, (2015).

[28]. Leonardo F. R. M, and et. al.; "Use of Recycled sand Produced at Construction Sites in Bedding Mortars”. J. Materials Civil Eng.Feb. 2013, Vol. 25, No. 2, pp. (263 - 242). 
International Journal of Engineering Technology and Scientific Innovation

ISSN: 2456-1851

Volume: 05, Issue: 01 "January-February 2020"

(2013).

[29]. Uy Shak and Others., (Effect of Partial Replacement of Fine Aggregate by Powder on Fresh and Hardened Properties of SCC. IGETER., Volume 6, Issue 8, August (2018). 